\title{
Formulation, Standardisation and Analysis of Natural Antioxidant Incorporated Breakfast Recipes
}

\author{
A. Priya ${ }^{1 *}$ and B. Vidhya ${ }^{2}$ \\ 'Rathnavel Subramaniam College of Arts and Science (Autonomous), Sulur, Coimbatore - 641402, Tamil Nadu, \\ India; priya.a@rvsgroup.com \\ 2Department of Foods and Nutrition, Rathnavel Subramaniam College of Arts and Science (Autonomous), Sulur, \\ Coimbatore -641402, Tamil Nadu, India; vidhyabalu28@gmail.com
}

\begin{abstract}
Pumpkin seed, grape seed, pomegranate peel and orange peel were dried in shadow powdered and it was incorporated in different traditional breakfast items such as idli, dosa, sevai, puttu and chapathi in three different variations $5 \%, 10 \%$ and $15 \%$. Sensory analysis revealed that $5 \%$ level incorporation was the most acceptable proportion in all the breakfast recipes. The nutrient analysis showed that the powdered peel and seed were rich in Vitamin C, E and $\beta$-carotene. The microbial study was also carried out till 15 days and the results showed that there were no microbial growth in the prepared powders and it was concluded that they were safe for consumption.
\end{abstract}

Keywords: Antioxidant, Nutrient and Microbial Analysis, Pomegranate Peels, Pumpkin Seeds

\section{Introduction}

"Food makes body work, grow and repair. Cooking gives variety of foods for human consumption. Various diseases are caused by lack of essential nutrients and can be corrected when all the nutrients are supplied, in a proper way. A well balanced diet is needed for maintenance of good health and healing of diseases" 1 . "Antioxidants are substances like vitamin $\mathrm{C}$, vitamin $\mathrm{E}$, beta carotene and enzymes which are capable of counteracting the damaging effects of oxidation"

"The pomegranate fruit peel also holds many health nutrients and antioxidant. It is found in recent studies that the peel contains double the antioxidants than the fruit, it also carries antibacterial, anti-inflammatory elements and large amount of vitamin C"3.

"Eating orange peels also provides tremendous benefit.
It is rich in vitamin $C$, as well as vitamin $A$, enzymes, fiber, and pectin. Vitamin $C$ is a fantastic immune system booster that can help to fight the symptoms of cold and flu. Dehydrated orange peel powder can even be added to a bath for an aroma therapeutic effect to cleanse the lungs of congestion or other respiratory irritation"4.

"Grape seed may be used to treat a range of health problems related to free radical damage, including heart disease, diabetes, and cancer. Grape seed extract has also been shown to protect against bacterial infections, such as Staphylococcus aureus. Some studies, mostly in animals, support these uses"

"Consuming fruits and vegetables of all kinds has long been associated with a reduced risk of many lifestylerelated health conditions. Many studies have suggested that increasing consumption of plant foods like pumpkin seeds decreases the risk of obesity, diabetes, heart 
disease, and overall mortality while promoting healthy complexion and hair growth." $\underline{6}$

\section{Methodology}

Antioxidant rich ingredients such as leftover fruit peels and seeds were selected purposely to improve health status.

Pomegranate peel and orange peel were available at home and grapes seed and pumpkin seeds were purchased from Pazhamudhir Nilayam in Tirupur city. Shadow drying technique was done to remove moisture content thereby preventing the growth of microorganisms and also to increase shelf life of the product. Drying is the thermal removal of liquid moisture from a material. The raw ingredients such as pumpkin seed, pomegranate peel, grape seed, orange peel were dried in shadow until the moisture is removed. All the ingredients were dried for 15 days, powdered and stored in air tight containers.

Traditional south Indian breakfast items like chapatti, dosa, idli, sevai and puttu were selected in which pumpkin seed, pomegranate peel, grapes seed and orange peel powders were incorporated into each recipe at $5 \%, 10 \%$, and $15 \%$ level ( Table 1 ).

The developed recipes were organoleptically evaluated by 30 semitrained panel members for appearance, texture, flavour, taste and overall acceptability. Nine point hedonic scaling was used for the evaluation.

Nutrient analysis such as ascorbic acid, carotenoids, and vitamin $\mathrm{E}$ were analysed in dried peels and seeds. All antioxidant powders were kept at room temperature for 15 days and the shelf life of antioxidant rich ingredients were assessed.

\section{Result and Discussion}

Among different variation of incorporation of antioxidant rich powders, variation 1 , (5 per cent) was highly acceptable when compared with other variations $(10 \%$ and $15 \%)$ in all the selected breakfast items (dosa,

Table 1. Standardization of antioxidant powders incorporated traditional breakfast items

\begin{tabular}{|c|c|c|c|c|c|c|c|c|c|}
\hline \multirow[b]{2}{*}{$\begin{array}{c}\text { Standard } \\
\text { product }\end{array}$} & \multirow[b]{2}{*}{$\begin{array}{l}\text { PP } \\
(\mathrm{g})\end{array}$} & \multirow[b]{2}{*}{$\begin{array}{l}\mathrm{OP} \\
(\mathrm{g})\end{array}$} & \multirow[b]{2}{*}{$\begin{array}{l}\text { PS } \\
(\mathrm{g})\end{array}$} & \multirow[b]{2}{*}{$\begin{array}{l}\text { GP } \\
(\mathrm{g})\end{array}$} & \multirow{2}{*}{$\begin{array}{l}\text { Chapatti } \\
\text { Wheat } \\
\text { flour (g) }\end{array}$} & \multicolumn{2}{|r|}{ Idly and dosa } & \multirow{2}{*}{$\begin{array}{c}\text { Puttu } \\
\text { Rice } \\
\text { flour } \\
(\mathrm{g}) \\
\end{array}$} & \multirow{2}{*}{$\begin{array}{c}\text { Sevai } \\
\text { Rice } \\
\text { flour } \\
(\mathrm{g})\end{array}$} \\
\hline & & & & & & $\begin{array}{c}\text { Rice } \\
\text { (g) }\end{array}$ & Black gram dhal(g) & & \\
\hline Standard & 0 & 0 & 0 & 0 & 100 & 75 & 25 & 100 & 100 \\
\hline $\mathrm{V}_{1}$ & 5 & 5 & 5 & 5 & 95 & 72.5 & 22.5 & 95 & 95 \\
\hline $\mathrm{V}_{2}$ & 10 & 10 & 10 & 10 & 90 & 70 & 20 & 90 & 90 \\
\hline $\mathrm{V}_{3}$ & 15 & 15 & 15 & 15 & 85 & 67.5 & 17.5 & 85 & 85 \\
\hline
\end{tabular}

PP- Pomegranate peel powder, OP- Orange peel powder,

PS- Pumpkin seed powder, GP- Grape seed powder, V1-Variation 1, V2-Variation 2, and V3-Variation 3.

Table 2. Nutrients and microbial count of antioxidant rich powder

\begin{tabular}{|c|c|c|c|c|}
\hline Nutrient & $\begin{array}{c}\text { Pomegranate peel } \\
\text { powder per 100 } \mathrm{g}\end{array}$ & $\begin{array}{c}\text { Orange peel } \\
\text { powder per } \\
\mathbf{1 0 0} \mathbf{g}\end{array}$ & $\begin{array}{c}\text { Grape seed } \\
\text { powder per } \\
\mathbf{1 0 0} \mathrm{g}\end{array}$ & $\begin{array}{c}\text { Pumpkin seed } \\
\text { powder per } \\
\mathbf{1 0 0} \mathbf{g}\end{array}$ \\
\hline Vitamin C (mg) & 0.1 & 120.26 & 40.8 & 96.6 \\
\hline Vitamin E (mg) & 0.02 & 0.17 & 0.03 & 10.6 \\
\hline$\beta$-Carotene (mg) & 0.001 & 0.004 & 0.063 & 0.903 \\
\hline $\begin{array}{c}\text { Aerobic plate count(15 } \\
\text { days) }\end{array}$ & Absent & Absent & Absent & Absent \\
\hline
\end{tabular}


idli, sevai, putu and chapatti).

Dehydration causes changes in the nutrient content of the product. However, the degree of changes largely depends on the dehydration technique and the dehydration treatments given. The pomegranate peel powder, orange peel powder, grapes seed powder, pumpkin seed powder were analyzed for nutrient content (Table 2).

It was noticed from the nutrient analysis that the selected antioxidant rich powders are high in vitamin $\mathrm{C}$, vitamin $\mathrm{E}$ and $\beta$-carotene. Thus, when these powders were incorporated in the food items the nutritional quality improves and has many health benefits. Microbial analysis of the prepared antioxidant rich powders (Pomegranate peel powder, Orange peel powder, Grape seed powder and Pumpkin seed powder ) reveals that the prepared powder can be stored for more than 15 days if, they were stored hygienically.

\section{Conclusion}

Traditional breakfast items prepared using peels and seeds of fruits such as pomegranate peel, orange peel, pumpkin seed and grape seed added at 5\% level were highly acceptable in all the attributes. The nutrient analysis of the prepared peel and seed of the fruit shows that they were rich in nutrients such as Vitamin C, E and $\beta$-carotene. Microbial analysis also shows that the prepared powders can be kept for 15 days if it is stored properly. Thus, the antioxidant rich fruit peel and powders which were highly recommended to control and prevent degenerative diseases. It was concluded that the peels and seeds of fruits which is rich in nutrient are not to be discarded; it should be utilized to enrich the human nutritional status.

\section{References}

1. Dr. Axe, top 10 antioxidant food + herbs, supplements. Available from: http://draxe.com.

2. Bill Lloyd MD, Anti-Antioxidant. 2007 Mar. Available from: http://blogs.webmd.com

3. Asha, Bold Sky Article. Available from: www.boldsky.com

4. Edward. The lung cleansing benefits of orange peel, global healing center.

5. University of Maryland Medical Center (UMMC); 2017. p. 1

6. Ware M. Pumpkin seeds: Health benefits, nutritional information. Medical News Today; 2017 Jan 18.

7. Gattat U, Sethi N, Kalyani S. Standardisation, organoleptic evaluation and biochemical evaluation of recipes using oats and flax seed. International Journal of Food and Nutritional Sciences (IJFANS). 2014 Jan-Mar; 3(1):47-55. 